\title{
ASSESSING THE ADOPTION OF MACRO PROPAGATION TECHNOLOGY (MPT) AMONG PLANTAIN AND BANANA FARMERS IN ONDO STATE, NIGERIA
}

\author{
Abdulrahman, O.L. ${ }^{1}$, Ogunlade, I. $^{2}$ and Omotesho, K.F. ${ }^{3}$
}

Correspondence author: O.L. Abdulrahman. Email: latifaht22@yahoo.com

\begin{abstract}
Despite efforts made on plantain and banana by agricultural research institutes, its production has not been remarkable. However, the potential of plantain and banana depends on the full utilisation of macro propagation technology which was introduced to the farmers. This study therefore assesses the socio-economics characteristics of plantain and banana farmers, as well as their attitude and adoption level in order to identify the factors responsible for adoption and to highlight the constraints to adoption of macro propagation technology in Ondo State, Nigeria. A sample of 120 respondents was randomly selected from the list of trained farmers. Data were collected by means of interviews using a structured questionnaire and analysed using descriptive and inferential statistics. Result show a mean age of 48.12 years, which does not encourage adoption, as well as a neutral attitude of farmers towards the technology (mean=2.98) and a low adoption level (mean=2.86). Furthermore, it was revealed that insufficient finances (51.7\%), inadequate technical know-how (51.7\%), and high cost of inputs (46.7\%) were severe constraints to adoption of macro propagation technology. The study found that educational status ( $p<0.05)$, farm size $(p<0.05)$, income $(p<0.05)$, and market link $(p<0.01)$ were positively significant with adoption of the technology and therefore concludes that educational level, income, farm size and market link are responsible for the adoption of macro propagation technology in Ondo State. Thus, the study recommends that more training be put into practice which takes into consideration the factors responsible for adoption. It is also important to incorporate youths into the training, and there should be proper monitoring after the training to ensure full adoption of macro propagation technology.
\end{abstract}

Keywords: Adoption, Attitude of farmers, Macro propagation technology, Plantain and banana farmers

\section{INTRODUCTION}

Plantain and banana (Musa sp.) are important staple food crops in the humid forest and mid altitudes of agro-ecological regions of sub-Saharan Africa which produce about $35 \%$ of promusa worldwide. They are also very crucial to global food security, employment and diversification of income in rural and urban areas (Darboe, 2011). Honfo, Tenkouano and

\footnotetext{
${ }^{1}$ Ph.D student, Department of Agricultural Extension and Rural Development, Faculty of Agriculture, University of Ilorin and Lecturer, Kwara State University, Malete, Nigeria. Email: latifaht22@yahoo.com, ORCID: 0000-0001-7736-0088

${ }^{2}$ Professor, Department of Agricultural Extension and Rural Development, Faculty of Agriculture, University of Ilorin, Nigeria, Email: israelogunlade @ gmail.com

${ }^{3}$ Senior Lecturer, Department of Agricultural Extension and Rural Development, Faculty of Agriculture, University of Ilorin, Nigeria, Email: kfomotesho@gmail.com
} 
S. Afr. J. Agric. Ext.

Vol. 47 No. 4, 2019: 96 - 105

http://dx.doi.org/10.17159/2413-3221/2019/v47n4a529
Abdulrahman, Ogunlade \&

Omotesho

(License: CC BY 4.0)

Coulibaly (2011) once noted Nigeria as one of the major plantain and banana producing and consuming countries in Africa and is ranked among the 20 most important producing countries in the world. The demand for plantain has increased tremendously in the last decade as a number of local processing industries have emerged using plantain and banana industrially for making flour, bread, cakes, chips, wine, juice and biscuits.

Plantain and banana are vegetative propagated in a wide variety of environments. They produce fruits all year round for up to one hundred years under a suitably managed cropping system and provide extremely valuable food sources during the hunger season. However, most farmers depend on natural regeneration of existing plantain and banana to obtain suckers (Ntamwira $e t$ $a l, 2017)$. This is a very slow process and usually does not yield adequate numbers of suckers. They are also a source of pests and diseases that reduce productivity and increase the cost of production due to the need for pest control measures. In this view, the International Institute for Tropical Agriculture (IITA) initiated and disseminated macro propagation technology to plantain and banana farmers in Ondo State through training. Njukwe et al (2014) reported macro propagation technology as user friendly which requires little technical know-how and equipment, hence, proving to be more attractive to adopt by farmers. It is within the farmers' reach because it is a field technique and cost efficient. It involves treatment of suckers to reduce the risk of transmitting soil-borne contaminants. Plantlets obtained through macro propagation have uniformity of seedlings while being less prone to post-established factors in the field, produces disease resistant varieties, increases yield, and produces a good quality of plantain and banana.

Despite the training received by plantain and banana farmers in Ondo State, Nigeria, its production is at an average annual yield of 17.5 tons/ha as compared to 26 tons/ha in Cameroon, which has still not been remarkable. This might be attributed to the attitude that farmers have towards macro propagation technology. Oyewumi and Adeniyi (2013) pointed out that attitude towards technology is very crucial since it is assumed as an explanatory factor that influences confidence, enthusiasm, inclination and aspiration to use a technology. When farmers are exposed to technology, but lack the right attitude towards the technology, they may not use it appropriately, and therefore the impact of such technology will not be felt.

Furthermore, it is important to note that when farmers use the technology inappropriately, the benefit which is supposed to be derived from using such technology will not prevail. The main aim of introducing new technology is for its widespread and adoption. Agricultural Research Institutes (ARIs), while developing technology, should be mindful of the information of socioeconomic characteristics of farmers that will adopt the technology. A number of socioeconomic characteristics of the farmers usually affect the extent to which technology is adopted, hence, there is a need for ARIs to have information on those characteristics. This is because it will go a long way in targeting the beneficiaries that will allow the training to have a maximum impact. A lack of information on the socio-economic characteristics might have a negative effect on adoption and utilisation of macro propagation technology.

However, the full realisation of plantain and banana potential depends on the adoption and utilisation of macro propagation technology which was introduced to the farmers. This study therefore assesses the adoption of macro propagation technology in Ondo State, Nigeria. 
Therefore, the main objective of the study was to assess the adoption of macro propagation technology while the specific objectives were to:

i. Describe the socio-economic characteristics of plantain and banana farmers,

ii. Determine the attitudes of plantain and banana farmers towards macro propagation technology,

iii. Investigate the adoption level of macro propagation technology,

iv. Identify the factors responsible for adoption of macro propagation technology, and

v. Highlight the constraints to adoption of macro propagation technology.

\subsection{Hypothesis of the study}

$\mathrm{H}_{0} 1$ : There is no significant relationship between selected socio-economic characteristics of plantain and banana farmers and adoption of macro propagation technology.

\section{METHODOLOGY}

The study was conducted in Ondo State, Nigeria. Ondo State is one of the states in the southwestern geopolitical zone of Nigeria. It is situated between latitudes $5045^{\prime}$ and $7052 ' \mathrm{~N}$ and longitudes 4020' and $6005^{\prime} \mathrm{E}$. Its land area is about 15500 square kilometres and is bounded to the east by Edo and Delta States, to the west by Ogun and Osun States, to the north by Ekiti and Kogi States, and to the south by the Bight of Benin and the Atlantic Ocean. Ondo State is majorly an agrarian State with over $60 \%$ of its labour force deriving their income from farming (Daramola et al, 2010). The temperature throughout the year ranges between $21^{\circ} \mathrm{C}$ and $29^{\circ} \mathrm{C}$ and humidity is relatively high. The annual rainfall varies from $2000 \mathrm{~mm}$ in the southern areas to $1150 \mathrm{~mm}$ in the northern areas.

The state enjoys luxuriant vegetation with high forest zone (rain forest) in the south and subsavannah forest in the northern fringe. Plantain and banana are predominantly produced in Ondo State with an average annual yield of 17.5 tons/ha (Ondo State Agricultural Development Programme (ADP), 2016). The farmers in the area also grow other cash crops such as kolanut, palm tree, coffee and food crops such as yams, maize, and cocoyam, mostly at subsistence level. Fishing activities and the production of tree crops such as cocoa, rubber, oil palm, cashew and forest tress like teak and indigenous tree species are also known within the area.

The target population for the study consisted of all trained plantain and banana farmers in Ondo State. A list of plantain and banana farmers was retrieved from Ondo State Agricultural Development Programme where 50\% of plantain and banana farmers were randomly selected, making a sample size of 120 respondents. Data were collected through a structured questionnaire and analysed using frequencies, percentages, mean scores and regression.

\section{RESULTS AND DISCUSSION}

Results in Table 1 indicate a mean age of 48.12 years which shows that plantain and banana farmers are ageing and no longer in their active age. This concurs with Fasina (2013) who reported that old age is not a good index for technology adoption because it affects activities of farmers and that farmers' productivity is deemed to decrease as they age. There were more males $(74.2 \%)$ than females $(25.8 \%)$ in the sample, while $96.7 \%$ of the farmers were married with no formal education $(82.5 \%)$. 
S. Afr. J. Agric. Ext.

Vol. 47 No. 4, 2019: 96 - 105

http://dx.doi.org/10.17159/2413-3221/2019/v47n4a529
Abdulrahman, Ogunlade \&

Omotesho

(License: CC BY 4.0)

The results also reveal that all of the participants engage in plantain and banana production, while $81.7 \%$ engage in sucker production. In addition, hired labour constituted $76.7 \%$ of the labour supply.

Table 1: Socio-economic characteristics of plantain and banana farmers

\begin{tabular}{|c|c|c|c|}
\hline Variables & $\begin{array}{l}\text { Frequency } \\
(\mathbf{n}=120)\end{array}$ & $\begin{array}{c}\text { Percentage } \\
(\%)\end{array}$ & Mean score \\
\hline \multicolumn{4}{|l|}{ Age (years) } \\
\hline $20-30$ & 5 & 4.2 & 48.12 \\
\hline $31-40$ & 24 & 20.0 & \\
\hline $41-50$ & 49 & 40.8 & \\
\hline $51-60$ & 31 & 25.8 & \\
\hline $61-70$ & 8 & 6.7 & \\
\hline 71 and above & 3 & 2.5 & \\
\hline \multicolumn{4}{|l|}{ Sex } \\
\hline Male & 89 & 74.2 & \\
\hline Female & 31 & 25.8 & \\
\hline \multicolumn{4}{|l|}{ Marital status } \\
\hline Divorced & 3 & 2.5 & \\
\hline Single & 1 & 0.8 & \\
\hline Married & 116 & 96.7 & \\
\hline \multicolumn{4}{|l|}{ Educational status } \\
\hline No formal education & 99 & 82.5 & \\
\hline Adult literacy & 8 & 6.7 & \\
\hline Primary education & 5 & 4.2 & \\
\hline Secondary education & 8 & 6.7 & \\
\hline Tertiary educations & 0 & 0.0 & \\
\hline Other & 0 & 0.0 & \\
\hline \multicolumn{4}{|l|}{ Source of labour } \\
\hline Family & 23 & 19.2 & \\
\hline Hired & 92 & 76.7 & \\
\hline Communal & 5 & 4.2 & \\
\hline \multicolumn{4}{|c|}{$\begin{array}{l}\text { Area of plantain and banana } \\
\text { enterprise }\end{array}$} \\
\hline Production & 120 & 100.0 & \\
\hline Marketing & 65 & 54.2 & \\
\hline Processing & 56 & 46.2 & \\
\hline $\begin{array}{l}\text { Sucker production } \\
* \text { multiple response }\end{array}$ & 98 & 81.7 & \\
\hline \multicolumn{4}{|l|}{ Access to farm credit } \\
\hline No & 76 & 63.3 & \\
\hline Yes & 44 & 37.7 & \\
\hline
\end{tabular}

Source: Field survey, 2017

Results in Table 2 show the attitude of plantain and banana farmers towards macro propagation technology (MPT). Accordingly, plantain and banana farmers derived the utmost satisfaction from using macro propagation technology with the highest mean score of 4.47. Similarly, 
S. Afr. J. Agric. Ext.

Vol. 47 No. 4, 2019: 96 - 105

http://dx.doi.org/10.17159/2413-3221/2019/v47n4a529
Abdulrahman, Ogunlade \&

Omotesho

(License: CC BY 4.0)

farmers started using the technology immediately after the training, but stopped afterwards, which was ranked second with a mean score of 4.23. Furthermore, farmers agreed to the fact that the technology has not increased their production level with a mean score of 4.23. They also concurred to the statement that they trained and encouraged other farmers to use MPT with a mean score of 3.92, they started using MPT immediately after training with a mean score of 3.87, while the sixth ranked attitude was that they did not agree that MPT was an expensive method which had a mean score of 3.86. In addition, plantain and banana farmers did not support the fact that MPT increased their production level, this ranked 16th with a mean score of 1.19. According to the result, the overall attitude of farmers towards MPT indicated neutral with a mean score of 2.86. This perhaps implies that their attitude is neither positive nor negative, probably because they are still understudying the technology. With all indications, attitude of plantain and banana farmers towards macro propagation technology is subject to change. This could also be attributed to the fact that plantain and banana farmers did not have adequate knowledge to handle the technology appropriately. This statement is similar to Meijer et al (2015) who stated that knowledge about an innovation determines the attitude towards it.

According to the results in Table 3, only 3\% of the respondents adopted the preparation of chamber by overlaying the inside with saw dust, $8 \%$ adopted obtaining of corm from growing pseudo stem of plantain and banana, $22 \%$ had treated the corm in mancoceb solution. Furthermore, 17\% adopted the cut-off of the meristem (growing) while 13\% adopted arrangement of the corm in the humidity chamber and cover completely with saw dust.

It could be deduced from Table 3 that the majority of these respondents tended to stop at certain stages of adoption, and none used the technology completely and continuously which eventually resulted to an average adoption level of 2.86. This shows a low adoption level of macro propagation technology among the respondents which could probably be due to the fact that these farmers did not get expected result as desired, or most of the steps in the technology are too technical for the respondents. The inability of the farmers to adopt macro propagation technology could also be attributed to some other factors. In some cases, the characteristics of a technology play a significant role. Mignouna et al (2011) in Ironkwe, Ezebuiro and Ewuziem (2016) reported that the characteristic of a technology plays a critical role in the adoption decision process. They argued that farmers who perceive the technology being consistent with their needs and compatible to their environment are likely to adopt since they view it as a positive investment. Farmers' perceptions about the performance of the technology significantly influences their decisions to adopt them. For ease of adoption, Karugia et al (2004) in Mwangi and Kariuki (2015) suggested that for any new technology to be introduced to farmers, they should be involved in its evaluation to find its suitability to their circumstances. 
S. Afr. J. Agric. Ext.

Vol. 47 No. 4, 2019: 96 -105

http://dx.doi.org/10.17159/2413-3221/2019/v47n4a529
Abdulrahman, Ogunlade \&

Omotesho

(License: CC BY 4.0)

Table 2: Attitude of farmers towards macro propagation technology

\begin{tabular}{|c|c|c|c|c|c|c|c|c|}
\hline $\mathbf{s} / \mathbf{n}$ & Attitudinal statement & SA & $\mathbf{A}$ & $\mathbf{U N}$ & D & SD & $\begin{array}{l}\text { Mean (Std. } \\
\text { dev.) }\end{array}$ & $\begin{array}{l}\text { Mean } \\
\text { Ranks }\end{array}$ \\
\hline 1. & $\begin{array}{l}\text { I derive utmost satisfaction while using macro propagation } \\
\text { technology. }\end{array}$ & $0(0.0)$ & $3(2.5)$ & $1(0.08)$ & $53(44.2)$ & $63(52.2)$ & $4.47(0.647)$ & $1^{\text {st }}$ \\
\hline 2 & $\begin{array}{l}\text { Macro propagation technology has assisted to increase the } \\
\text { quality of my produce. }\end{array}$ & $43(35.8)$ & $61(50.8)$ & $8(6.7)$ & $0 .(0.0)$ & $8(6.7)$ & $1.91(1.012)$ & $15^{\text {th }}$ \\
\hline 3 & $\begin{array}{l}\text { I started using macro propagation technology immediately after } \\
\text { training. }\end{array}$ & $4(3.3)$ & $33(27.5)$ & $0(0.0)$ & $21(17.5)$ & $62(51.7)$ & $3.87(1.384)$ & $5^{\text {th }}$ \\
\hline 4 & $\begin{array}{l}\text { I train and encourage other plantain and banana farmers to use } \\
\text { macro propagation technology. }\end{array}$ & $0(0.0)$ & $28(23.3)$ & $12(10.0)$ & $18(15.0)$ & $62(51.7)$ & $3.92(1.249)$ & $4^{\text {th }}$ \\
\hline 5 & $\begin{array}{l}\text { The foreign exchange capacity of the nation can be boosted by } \\
\text { practicing macro propagation technology. }\end{array}$ & $12(10.0)$ & $32(26.7)$ & $11(9.2)$ & $49(40.8)$ & $16(13.3)$ & $3.21(1.256)$ & 7 th \\
\hline 6 & $\begin{array}{l}\text { I do not get enough suckers I need after using macro } \\
\text { propagation technology. }\end{array}$ & $34(28.3)$ & $20(16.7)$ & $17(14.2)$ & $9(7.5)$ & $40(33.3)$ & $3.01(1.653)$ & $11^{\text {th }}$ \\
\hline 7 & $\begin{array}{l}\text { I never wish to join cooperative purposely for macro } \\
\text { propagation technology practice. }\end{array}$ & $10(8.3)$ & $60(50.0)$ & $3(2.5)$ & $29(24.2)$ & $18(15.0)$ & $3.13(1.294)$ & $10^{\text {th }}$ \\
\hline 8 & Macro propagation technology is difficult to practice. & $21(17.5)$ & $11(9.2)$ & $62(51.7)$ & $16(13.3)$ & $10(8.3)$ & $2.86(1.117)$ & $12^{\text {th }}$ \\
\hline 9 & $\begin{array}{l}\text { Macro propagation technology has not increased my } \\
\text { production level }\end{array}$ & $48(40.0)$ & $59(49.2)$ & $5(4.2)$ & $8(6.7)$ & $0(0.0)$ & $4.23(0.814)$ & $3^{\text {rd }}$ \\
\hline 10 & $\begin{array}{l}\text { Macro propagation technology has not helped to produce } \\
\text { disease free suckers. }\end{array}$ & $33(27.5)$ & $52(43.3)$ & $4(3.3)$ & $20(16.7)$ & $11(9.2)$ & $2.37(1.296)$ & $14^{\text {th }}$ \\
\hline 11 & $\begin{array}{l}\text { I started using macro propagation technology immediately after } \\
\text { the training but stopped afterwards. }\end{array}$ & $50(41.7)$ & $52(43.3)$ & $18(15.0)$ & $0(0.0)$ & $0(0.0)$ & $4.27(0.707)$ & $2 \mathrm{nd}$ \\
\hline 12 & Macro propagation technique is not a good/useful practice. & $34(28.3)$ & $33(27.5)$ & $8(6.7)$ & $8(6.7)$ & $37(30.8)$ & $3.16(1.645)$ & $8^{\text {th }}$ \\
\hline 13 & $\begin{array}{l}\text { My customers complain about the quality of my produce when } \\
\text { I started using macro propagation technology. }\end{array}$ & $70(58.3)$ & $25(20.8)$ & $17(14.17)$ & $5(4.17)$ & $3(2.5)$ & $3.14(1.117)$ & $9^{\text {th }}$ \\
\hline 14 & I harvest my produce anytime am constrain financially. & $58(48.3)$ & $14(11.7)$ & $4(3.3)$ & $25(20.8)$ & $19(15.8)$ & $2.44(1.613)$ & $13^{\text {th }}$ \\
\hline 15 & It is an expensive method for me. & $30(25.0)$ & $69(57.5)$ & $4(3.3)$ & $8(6.7)$ & $9(7.5)$ & $3.86(1.102)$ & $6^{\text {th }}$ \\
\hline \multirow[t]{2}{*}{16} & $\begin{array}{l}\text { It is not essential to follow strictly the } 10 \text { steps of macro } \\
\text { propagation technology }\end{array}$ & $4(3.3)$ & $20(16.7)$ & $9(7.5)$ & $43(35.8)$ & $44(36.7)$ & $3.86(1.183)$ & $6^{\text {th }}$ \\
\hline & Overall mean score $=2.86 ;$ Benchmark $=3.0$ & & & & & & 2.86 & \\
\hline
\end{tabular}


S. Afr. J. Agric. Ext.

Vol. 47 No. 4, 2019: 96 -105

http://dx.doi.org/10.17159/2413-3221/2019/v47n4a529
Abdulrahman, Ogunlade \&

Omotesho

(License: CC BY 4.0)

Table 3: Adoption level of macro propagation technology among plantain and banana farmers

\begin{tabular}{|c|c|c|c|c|c|c|c|}
\hline $\mathbf{s} / \mathbf{n}$ & Steps & Awareness & Interest & Evaluation & Trial & Adoption & Mean (std dev.) \\
\hline 1 & $\begin{array}{l}\text { Preparation of the } \\
\text { humidity chamber by } \\
\text { over laying the inside } \\
\text { with saw dust. }\end{array}$ & $54(45.0)$ & $13(10.8)$ & $21(17.5)$ & $29(24.2)$ & $3(2.5)$ & $2.28(1.323)$ \\
\hline 2 & $\begin{array}{l}\text { Obtaining plantain/ } \\
\text { banana corm from } \\
\text { growing pseudo } \\
\text { stem. }\end{array}$ & $36(30.0)$ & $8(6.7)$ & $58(48.3)$ & $10(8.3)$ & $8(6.7)$ & $2.55(1.194)$ \\
\hline 3 & $\begin{array}{l}\text { Treating of corm in } \\
\text { mancoceb solution } \\
\text { by soaking it for } \\
\text { about } 3 \text { seconds } \\
\text { intermitently. }\end{array}$ & $23(19.2)$ & $15(12.5)$ & $45(37.5)$ & $15(12.5)$ & $22(18.3)$ & $2.98(1.328)$ \\
\hline 4 & $\begin{array}{l}\text { Cutting off the } \\
\text { meristem (growing } \\
\text { point) in cross bar } \\
\text { shape. }\end{array}$ & $22(18.3)$ & $14(11.7)$ & $54(45.0)$ & $13(10.8)$ & $17(14.2)$ & 2.91(1.237) \\
\hline 5 & Allowing to cool & $12(10.0)$ & $20(16.7)$ & $29(24.2)$ & $38(31.7)$ & $21(17.5)$ & $3.30(1.221)$ \\
\hline 6 & $\begin{array}{l}\text { Arranging the corm } \\
\text { in the humidity } \\
\text { chamber and } \\
\text { covering completely } \\
\text { with saw dust. }\end{array}$ & $17(14.2)$ & $16(13.3)$ & $60(50.0)$ & $14(11.7)$ & $13(10.8)$ & $2.92(1.120)$ \\
\hline 7 & $\begin{array}{l}\text { Adding water daily to } \\
\text { keep the chamber wet } \\
\text { for two weeks. }\end{array}$ & $21(17.5)$ & $16(13.3)$ & $45(37.5)$ & $20(16.7)$ & $18(15.0)$ & $2.98(1.270)$ \\
\hline 8 & $\begin{array}{l}\text { Cutting the } \\
\text { germinated plantlet } \\
\text { off the sprouting } \\
\text { corm as it } \\
\text { germinates. }\end{array}$ & $24(20.0)$ & $16(13.3)$ & $63(52.5)$ & $14(11.7)$ & $3(2.5)$ & $2.63(1.012)$ \\
\hline 9 & $\begin{array}{l}\text { Transferring of } \\
\text { plantlets into } \\
\text { polythene bags in the } \\
\text { nursery. }\end{array}$ & $17(14.2)$ & $8(6.7)$ & $56(46.7)$ & $12(10.0)$ & $27(22.5)$ & $3.20(1.268)$ \\
\hline
\end{tabular}

Source: Field survey, 2017

Table 4 reveals that some constraints hinder adoption of macro propagation technology among which are insufficient finances $(51.7 \%)$, inadequate technical know-how (51.7\%), high cost of inputs $(46.7 \%)$, and inadequate labour $(53.3 \%)$ which were all highly severe. In the same vein, pest and disease attacks $(60.8 \%)$ and high levels of produce deterioration $(71.7 \%)$ were moderately severe. 
S. Afr. J. Agric. Ext.

Vol. 47 No. 4, 2019: 96 -105

http://dx.doi.org/10.17159/2413-3221/2019/v47n4a529
Abdulrahman, Ogunlade \&

Omotesho

(License: CC BY 4.0)

Table 4: Constraints to adoption of macro propagation technology

\begin{tabular}{|l|l|c|c|c|c|}
\hline $\mathbf{s} / \mathbf{n}$ & Constraints & $\begin{array}{c}\text { Highly severe } \\
(\mathbf{\%})\end{array}$ & $\begin{array}{c}\text { Moderately } \\
\text { severe }\end{array}$ & Not severe & Mean score \\
\hline 1 & $\begin{array}{l}\text { Insufficient } \\
\text { finances }\end{array}$ & $62(51.7)$ & $50(41.7)$ & $8(6.7)$ & $2.45(0.620)$ \\
\hline 2 & $\begin{array}{l}\text { Non-availability of } \\
\text { land/ land tenure } \\
\text { system }\end{array}$ & $48(40.0)$ & $63(52.5)$ & $9(7.5)$ & $2.35(0.657)$ \\
\hline 3 & $\begin{array}{l}\text { Pest and disease } \\
\text { attacks }\end{array}$ & $28(23.3)$ & $73(60.8)$ & $19(15.8)$ & $2.08(0.624)$ \\
\hline 4 & Inadequate labour & $64(53.3)$ & $34(28.3)$ & $22(18.3)$ & $2.35(0.774)$ \\
\hline 5 & $\begin{array}{l}\text { Poor transportation } \\
\text { system }\end{array}$ & $32(26.7)$ & $74(61.7)$ & $14(11.7)$ & $2.15(0.603)$ \\
\hline 6 & $\begin{array}{l}\text { High level of } \\
\text { produce } \\
\text { deterioration. }\end{array}$ & $22(18.3)$ & $86(71.7)$ & $12(10.0)$ & $2.08(0.528)$ \\
\hline 7 & Inadequate water & $12(10.0)$ & $61(50.0)$ & $47(39.2)$ & $1.88(0.805)$ \\
\hline 8 & Insecurity & $32(26.7)$ & $41(34.2)$ & $47(39.2)$ & $1.88(0.805)$ \\
\hline 9 & $\begin{array}{l}\text { Poor access to } \\
\text { fertilizer }\end{array}$ & $52(43.3)$ & $49(40.8)$ & $19(15.8)$ & $2.280(0.721)$ \\
\hline 11 & Poor sales & $29(24.2)$ & $67(55.8)$ & $24(20.0)$ & $2.040(0.666)$ \\
\hline 12 & $\begin{array}{l}\text { Inadequate } \\
\text { technical } \\
\text { knowledge }\end{array}$ & $62(51.7)$ & $20(16.7)$ & $38(31.7)$ & $1.85(0.682)$ \\
\hline 15 & High cost of inputs & $56(46.7)$ & $53(44.2)$ & $11(9.2)$ & $2.35(0.643)$ \\
\hline $50 u r e:$ Field survey, 2017 & & & & & \\
\hline
\end{tabular}

Source: Field survey, 2017

The results of the socio-economic determinants of adoption of macro propagation are shown in Table 5. The output shows that educational status $(\mathrm{t}=2.179, \mathrm{p}=0.032)$, income $(\mathrm{t}=2.051$, $\mathrm{p}=0.043)$, farm size $(\mathrm{t}=2.194, \mathrm{p}=0.030)$, and market linkage $(\mathrm{t}=3.639, \mathrm{t}=0.000)$ were determinants of adoption of macro propagation technology by respondents. Educational status, income and farm size had positive relationships with adoption. This implies that as respondents continue to advance in their educational level, generate more income, expand their farm size, and have access to markets, they tend to be more willing to adopt macro propagation technology. This result is in agreement with the findings of Melese (2018) in the adoption of technology. This result further confirms that farmers with small farm sizes may be credit constrained, and such resource poor farmers may not be able to purchase key inputs which will eventually hinder the adoption of technology. 
S. Afr. J. Agric. Ext.

Vol. 47 No. 4, 2019: 96 -105

http://dx.doi.org/10.17159/2413-3221/2019/v47n4a529
Abdulrahman, Ogunlade \&

Omotesho

(License: CC BY 4.0)

Table 5: Regression analysis showing socio-economic determinants of adoption of macro propagation technology by plantain and banana farmers

\begin{tabular}{|l|c|c|c|c|c|}
\hline \multirow{2}{*}{ Model } & \multicolumn{2}{|c|}{$\begin{array}{c}\text { Unstandardized } \\
\text { Coefficients }\end{array}$} & $\begin{array}{c}\text { Standardized } \\
\text { Coefficients }\end{array}$ & \multirow{2}{*}{ T } & \multirow{2}{*}{ Sig. } \\
\cline { 2 - 5 } & $\mathbf{( B )}$ & $\begin{array}{c}\text { Std. } \\
\text { Error }\end{array}$ & Beta & & \\
\hline (Constant) & 4.180 & 1.580 & & 2.646 & .009 \\
\hline Sex & .183 & .276 & .063 & .661 & .510 \\
\hline Marital status & .038 & .379 & .010 & .099 & .921 \\
\hline Age & -.016 & .013 & -.121 & -1.210 & .229 \\
\hline Educational status & $.121^{*}$ & .085 & .202 & 2.179 & .032 \\
\hline Income & $.253^{*}$ & .000 & .200 & 2.051 & .043 \\
\hline Household size & .038 & .075 & .054 & .503 & .616 \\
\hline Farm size & $.410^{*}$ & .187 & .222 & 2.194 & .030 \\
\hline Market link & $1.129 * *$ & .310 & 410 & 3.639 & .000 \\
\hline Dependent variable: Adoption level & & & & & \\
\hline R=.706 & & & & & \\
\hline R Square =.498 & $\mathbf{4 9 . 8 \%}$ & & & & \\
\hline Adjusted R Square $=.447$ & & & & & \\
\hline Std. Error of the Estimate $=0.984$ & & & & & \\
\hline F-Statistics = 9.755 & & & & & \\
\hline Sum of square residual =104.521 & & & & & \\
\hline
\end{tabular}

Source: Field survey, 2017. Note: ** Significant at 1\%, * Significant a 5\%

\section{CONCLUSION AND RECOMMENDATIONS}

Attitude of plantain and banana farmers towards macro propagation technology was neutral which resulted in a low adoption level of MPT in the study area. It was also discovered that insufficient funds, inadequate technical know-how and high cost of inputs were highly severe constraints to adoption of MPT. Educational level, income, farm size and market link were found to be the significant factors responsible for adoption of MPT.

There is a need to re-train plantain and banana farmers on the use of macro propagation technology. While training, it is important to involve these farmers during the evaluation of the technology so that the need for adopting the technology will be felt. Total monitoring of these famers should be ensured, which could bring about a change in their attitude towards the technology. Efforts should also be made towards counteracting the constraints recorded against the adoption of MPT.

\section{REFERENCES}

DARAMOLA, J.O., ADEKUNLE, M.F., OLANIYAN, M.O. \& ALAYAKI, F.M., 2010. Ondo State Diagnostic Survey Report. IFSERAR. Abeokuta, Nigeria.

DARBOE, L., 2011. Study on banana value chain in the Gambia. NARI. Papua New Guinea.

FASINA, O.O., 2013. Farmers perception of the effect of aging on their agricultural activities in Ondo State, Nigeria. Available from: https://core.ac.uk/download/pdf/25992050.pdf 
HONFO, F.G., TENKOUANO, A. \& COULIBALY, O., 2011. Banana and plantain-based foods consumption by children and mothers in Cameroon and Southern Nigeria: A comparative study. Afr. J. Food Sci., 5(5):287-291.

IRONKWE, A.G., EZEBUIRO, N.C. \& EWUZIEM, J.E., 2016. Adoption of root and tuber technologies disseminated by the National Root Crops Research Institute in Anambra State. J. Agric. Ext., 20(1):39-52.

KARUGIA, S., BALTENWECK, I., WAITHAKA, M., MIANO, M., NYIKAL, R. \& ROMNEY, D., 2004. Perception of technology and its impact on technology uptake: The case of fodder legume in Central Kenya Highlands. In The Role of Social Scientists Proceedings of the Inaugural Symposium. Nairobi, Kenya, pp.1-11.

MEIJER, S.S., CATACUTAN, D., AJAYI, O.C., SILESHI, G.W. \& NIEUWENHUIS, M., 2015. The role of knowledge, attitudes and perceptions in the uptake of agricultural and agroforestry innovations among smallholder farmers in sub-Saharan Africa. Int. J. Agric. Sustain., 13(1):40-54.

MELESSE, B., 2018. A Review on Factors Affecting Adoption of Agricultural New Technologies in Ethiopia. Journal of Agricultural Science and Food Research. 9(3): Issue 3.

MIGNOUNA, D.B., MANYONG, V.M., RUSIKE, J., MUTABAZI, K.D.S. \& SENKONDO, E.M., 2011. Determinants of adopting imazapyr-resistant maize technologies and its impact on household income in Western Kenya. AgBioForum., 14(3):158-163.

MWANGI, M. \& KARIUKI, S., 2015. Factors determining adoption of new agricultural technology by smallholder farmers in developing countries. J. Econ. Sust. Dev., 6(5):208217.

NJUKWE, E., OUMA, E., VAN ASTEN, P.J.A., MUCHUNGUZI, P. \& AMAH, D., 2014. Challenges and opportunities for macro propagation technology for Musa sp. among smallholder farmers and small and medium scale enterprises. In Banana systems in the humid highlands of Sub-Saharan Africa (pp.66-71). Oxfordshire: CABI.

NTAMWIRA, J., SIVIRIHAUMA, C., OCIMATI, W., BUMBA, M., VUTSEME, L., KAMIRA, M. \& BLOMME, G., 2017. Macropropagation of banana/plantain using selected local materials: A cost-effective way of mass propagation of planting materials for resource-poor households. Eur. J. Hortic. Sci., 82(1):38-53.

ONDO STATE AGRICULTURAL DEVELOPMENT PROGRAMME REPORT, 2016.

OYEWUMI, A. \& ADENIYI, S.O., 2013. Assessing attitude to and knowledge of entrepreneurship among students with hearing impairment in Nigeria. Int. Multidiscip. J. Ethiop., 7(3):127-142. 
